\title{
Genotyping Ocular Strains of Chlamydia trachomatis by Single-tube Nested PCR
}

\author{
Suphat Pecharatana, Mark A. Pickett, Peter J. Watt, and Michael E. Ward
}

Department of Molecular Microbiology, University Medical School, Southampton General Hospital, Southampton, SO9 4XY, UK

\begin{abstract}
A single-tube nested PCR able to discriminate between ocular infection with Chlamydia trachomatis of serovar A, B, or C is described. The method uses genotype-specific primers labeled with different fluorochromes, "drop-in/drop-out" PCR amplification, and product analysis on an Applied Blosystems 373A DNA Sequencer using GENESCAN 672 software. The system readily detected mixed infection with serotypes $A$ and $B$ within the same eye. This strategy provides a rapid genotyping method applicable to a wide variety of epidemiological studies.
\end{abstract}

hlamydia trachomatis is an obligate intracellular bacterium of major clinical significance. Worldwide, $C$. trachomatis is a frequent cause of sexually transmitted disease and has important sequelae, for example, infertility and extrauterine pregnancy. C. trachomatis serotypes A, B, and $C$ are the etiological agents of trachoma, one of the major causes of preventable blindness in the world. As chlamydiae are difficult to grow in cell culture, PCR-based detection has obvious advantages. Antibodies to the surface-exposed loops on the major outer membrane protein (MOMP), encoded by variable segments (VS) I, II, and IV of the MOMP gene, are protective. Details of the genotype and variant distribution are crucial for chlamydial vaccine design and epidemiological studies.

Genotyping of C. trachomatis has been achieved by restriction endonuclease cleavage of PCR-amplified MOMP DNA, ${ }^{(1-3)}$ or nested PCR based on typespecific regions of the MOMP gene. ${ }^{(4)}$ This nested PCR requires tube opening to decrease the concentration of the outer primers and to add the inner (nested) primers. The procedure is inconvenient and significantly increases the risk of cross-contaminating the sec- ondary reactions with amplified products from the first reaction.

An attractive alternative is to mix the outer and inner primers together in a single reaction. A thermal profile is chosen that initially allows only the outer primers to take part in amplification; subsequently, the inner primers amplify the nested fragment. This technique has been termed "drop-in/drop-out" nested PCR. ${ }^{(5)}$ The original use was to amplify a single human immunodeficiency virus (HIV) template in the background of genomic DNA from 70,000 cells.

We have developed a single-tube "drop-in/drop-out" nested PCR able to discriminate between ocular infection with C. trachomatis of serotype A, B, or C. Genotype-specific PCR primers are labeled with different fluorochromes, and the reaction products are analyzed by denaturing polyacrylamide gel electrophoresis on an Applied Biosystems 373A DNA Sequencer using GENESCAN 672 software.

\section{MATERIALS AND METHODS}

\section{Sample Collection and Preparation}

The study was based in the villages of Jali and Berending, The Gambia, West Af-

TABLE 1 Primers Used for Drop-in/Drop-out Chlamydial Genotyping PCR

\begin{tabular}{lll}
\hline & $\begin{array}{l}\text { Melting } \\
\text { temperature } \\
\left({ }^{\circ} \mathrm{C}\right)^{(8)}\end{array}$ & Sequence $\left(5^{\prime} \rightarrow 3^{\prime}\right)$ \\
\hline Outer primers & & \\
FLS & 59 & CT C TTGAAATCGGT T T AGTATTTGCCGCT \\
FLA & 61 & TT A GAA I CGGAAT TGTGCATTT ACGTGAGC \\
Nested primers & & \\
ABC-1 & 46 & AC A / TGATGTGAATAAAGAA \\
A-1/FAM & 46 & FAM - CAGTGT TAGGAACAATA \\
B-1/JOE & 48 & JO E - CTTTAGTCTGGT TCTCA \\
C-1/TAMRA & 48 & TAMRA - CAGTGTTAGGAATAAGC \\
\hline
\end{tabular}




\section{\begin{tabular}{|l|l|l|l|l|l|l|}
\hline VS-I VS-II & Omp 1 gene
\end{tabular}}
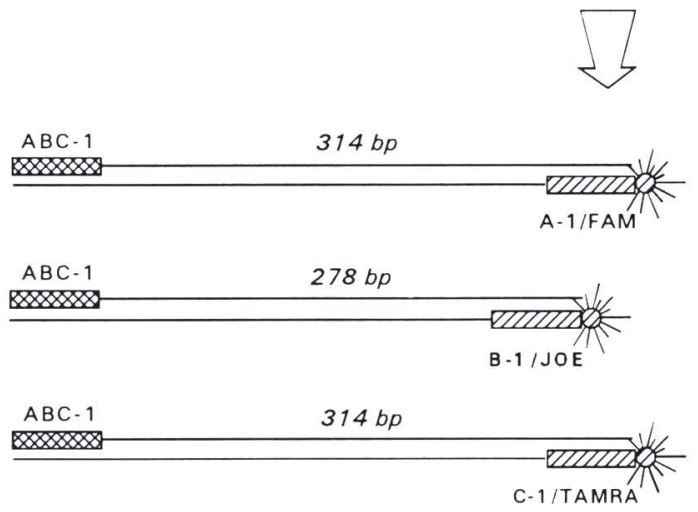

FIGURE 1 Schematic of primer selection based on the MOMP gene of $C$. trachomatis. Outer primers FLS and FLA were chosen from a region conserved sequence in $C$. trachomatis serotypes. For the nested primers, ABC-1 was selected from the conserved sequence downstream from FLS, and the genotyping primers A-1, B-1, and C-1 were selected from variable segment II. These genotype-specific primers were labeled with fluorescent dyes (FAM, JOE, or TAMRA). All six primers were used in each drop-in/drop-out PCR.

rica. A total of 1364 conjunctival swabs were obtained in the villages by Dr. R. Bailey and colleagues from both clinically negative individuals and trachoma cases. Swabs were taken from the upper subtarsal conjunctiva and immediately expressed into $1 \mathrm{ml}$ of chlamydial antigen detection transport medium (IDEIA, Novobiolabs, Cambridge, UK). All cells and bacteria suspended in the transport medium were pelleted by centrifugation $(13,000 \mathrm{rpm}, 30 \mathrm{~min})$ and then incubated with $2 \mu \mathrm{g}$ of proteinase $\mathrm{K}$ in $50 \mu \mathrm{l}$ of $0.5 \%$ Tween $20 / 0.5 \% \mathrm{NP}-40$ at $60^{\circ} \mathrm{C}$ for $60 \mathrm{~min}$. Proteinase $\mathrm{K}$ was inactivated by heating the samples to $100^{\circ} \mathrm{C}$ for 10 min. ${ }^{(6)}$

The $C$. trachomatis strains A/SA-1/OT, B/Jali-20/OT, and C/UW-1/OT were used as positive controls for genotyping. Elementary bodies (EBs), prepared by the method of Salari and Ward, ${ }^{(7)}$ were tested at concentrations of $10^{3}-10^{5} / \mathrm{ml}$.

\section{Oligonucleotide Design and Synthesis}

Six oligonucleotides were selected based on the nucleotide sequence of the MOMP gene (Table 1). The outer primers, FLS and FLA, were chosen from a region of sequence conserved in all $C$. trachomatis serotypes. For nested primers, ABC-1 was selected from the conserved sequence downstream of FLS and the three genotyping primers A-1, B-1, and C-1 from variable segment II (Fig. 1). The outer primers, $30 \mathrm{bp}$ in length, were predicted to exhibit higher melting temper-

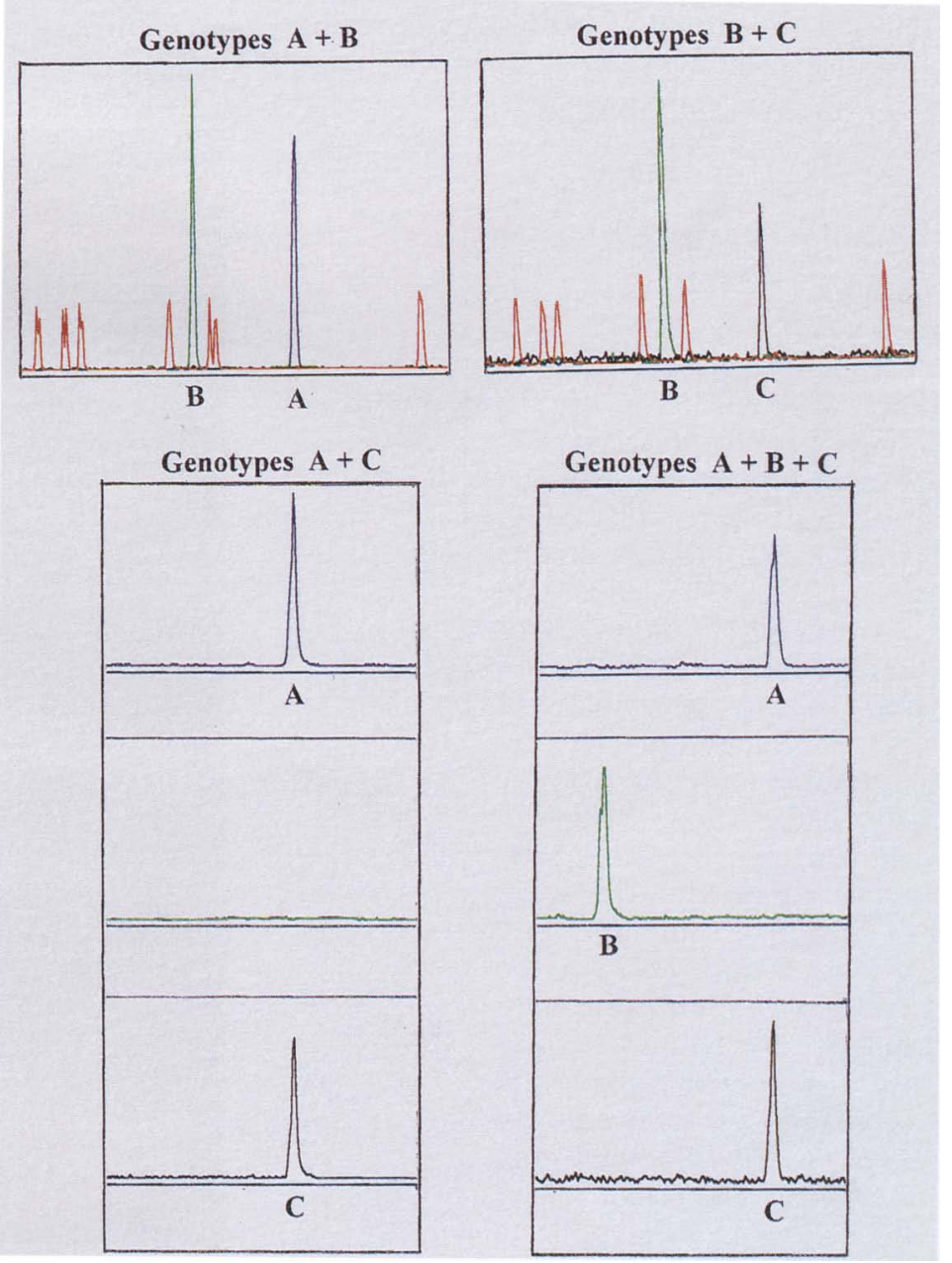

FIGURE 2 Genotype PCR specificity. All combinations of $C$. trachomatis serotypes A, B, and C were tested in single-tube PCR. Genotypes $A+B$ or $B+C$ were readily distinguished by size difference in the PCR product. The electrophoretograms from single-tube $A+C$ or $A+B+C$ reactions are presented as individual tracks to separate genotypes $A$ and $C$, which are distinguished by fluorochrome label, not size [Note that in this presentation the red size marker tracks are removed.] In all tests the genotyping primers A-1/FAM, B-1/JOE, and C-1/TAMRA showed complete specificity for DNA from the corresponding serotype. 
atures than shorter, inner primers (Table 1). All primers were designed to avoid both regions of secondary structure and primer-dimer formation at their 3 ' ends. Oligonucleotide synthesis was performed on an Applied Biosystems 381A DNA Synthesizer. The nested primers A-1, B-1, and C-1 were derivatized with a free primary amino group at their 5 ' end using AminoLink 2 phosphoramidite (Applied Biosystems).

\section{Fluorescent Labeling of Oligonucleotides}

Genotype-specific primers were labeled with fluorescent dyes: primer A-1 with FAM-NHS ester, B-1 with JOE-NHS ester, and $\mathrm{C}-1$ with TAMRA-NHS ester, according to the manufacturer's instructions (Applied Biosystems). The fluorescently labeled primers were purified by gel filtration followed by reverse-phase HPLC. The purified oligonucleotide primers were stored at $-20^{\circ} \mathrm{C}$ in the dark.

\section{PCR Amplification Reaction}

PCR amplification reactions were performed in a total volume of $50 \mu \mathrm{l}$. Each reaction contained $2 \mu$ l of extracted DNA from conjunctival swabs or $2 \mu$ l of control DNA from C. trachomatis serotype A, $\mathrm{B}$, or $\mathrm{C}$; the outer primers FLS and FLA (0.5 pmole each); inner primers $A B C-1$, A-1/FAM, B-1/JOE, C-1/TAMRA (10 pmoles each); dATP, dCTP, dGTP, dTTP (10 nmoles each); $\mathrm{KCl}$ (2.5 $\mu$ moles $) ;$ Tris$\mathrm{HCl}$ ( $\mathrm{pH} 8.3$ ) (0.5 $\mu$ mole); $\mathrm{MgCl}_{2}$ (75 nmoles), and Taq DNA polymerase (1 unit; Promega, Southampton, UK). AmpliWax beads (Perkin-Elmer Cetus) were used to facilitate the "hot start" technique. ${ }^{(5)}$ Following the hot start, samples were subjected to 15 cycles each, consisting of $94^{\circ} \mathrm{C}$ for $1 \mathrm{~min}, 60^{\circ} \mathrm{C}$ for 2 $\mathrm{min}$, and $72^{\circ} \mathrm{C}$ for $3 \mathrm{~min}$. This was followed by 2 cycles of $94^{\circ} \mathrm{C}$ for $1 \mathrm{~min}, 48^{\circ} \mathrm{C}$ for $1 \mathrm{~min}$, and $72^{\circ} \mathrm{C}$ for $1.5 \mathrm{~min}$, then 28 cycles each consisting of $85^{\circ} \mathrm{C}$ for $1 \mathrm{~min}$, $48^{\circ} \mathrm{C}$ for $1 \mathrm{~min}$, and $72^{\circ} \mathrm{C}$ for $1 \mathrm{~min}$ and $30 \mathrm{sec}$ followed by an additional $7 \mathrm{~min}$ of extension at $72^{\circ} \mathrm{C}$. The samples were stored at $4^{\circ} \mathrm{C}$ following PCR, prior to analysis.

\section{RESULTS AND DISCUSSION}

During the development of this PCR system for genotyping ocular strains of $C$. trachomatis, the temperature conditions and number of cycles for each step were systematically modified to obtain optimal sensitivity and selectivity. The electrophoretogram (Fig. 2) demonstrates that the developed method accurately identified any combination of serotypes $\mathrm{A}, \mathrm{B}$, and $\mathrm{C}$ within a single PCR. The direct application of genotyping PCR to conjunctival swabs from trachoma patients is shown in Figure 3. In this gel picture, generated by GENESCAN software, the internal size standards appear red and the genotype-specific amplification products from serotypes $\mathrm{A}, \mathrm{B}$, and $\mathrm{C}$ are blue, green, and yellow, respectively. The blue and yellow fragments are generated by primers to the same segment of the MOMP gene and exhibit identical sizes (314 bp). The green fragments specific for serotype $B$ represent amplifica- tion products of $278 \mathrm{bp}$. In patients with mixed A and B ocular chlamydial infection, both fragments are present in the same track; this is most easily seen in the electrophoretogram (Fig. 4).

Of the 1363 villagers screened for $C$. trachomatis ocular infection, genotype A was detected in 136 samples, genotype $B$ in 31, and 12 had mixed A and B infections. Genotype $C$ was not observed. To confirm the specificity of PCR genotyping, we sequenced both strands of variable segments I, II, and IV of PCR-amplified MOMP gene from all positive clinical samples. There was complete concordance between $\mathrm{A}$ and $\mathrm{B}$ genotyping and the DNA sequence analysis data. The sequence results also confirmed the cases of mixed A plus B infections. At sites where the $A$ and $B$ sequences differ

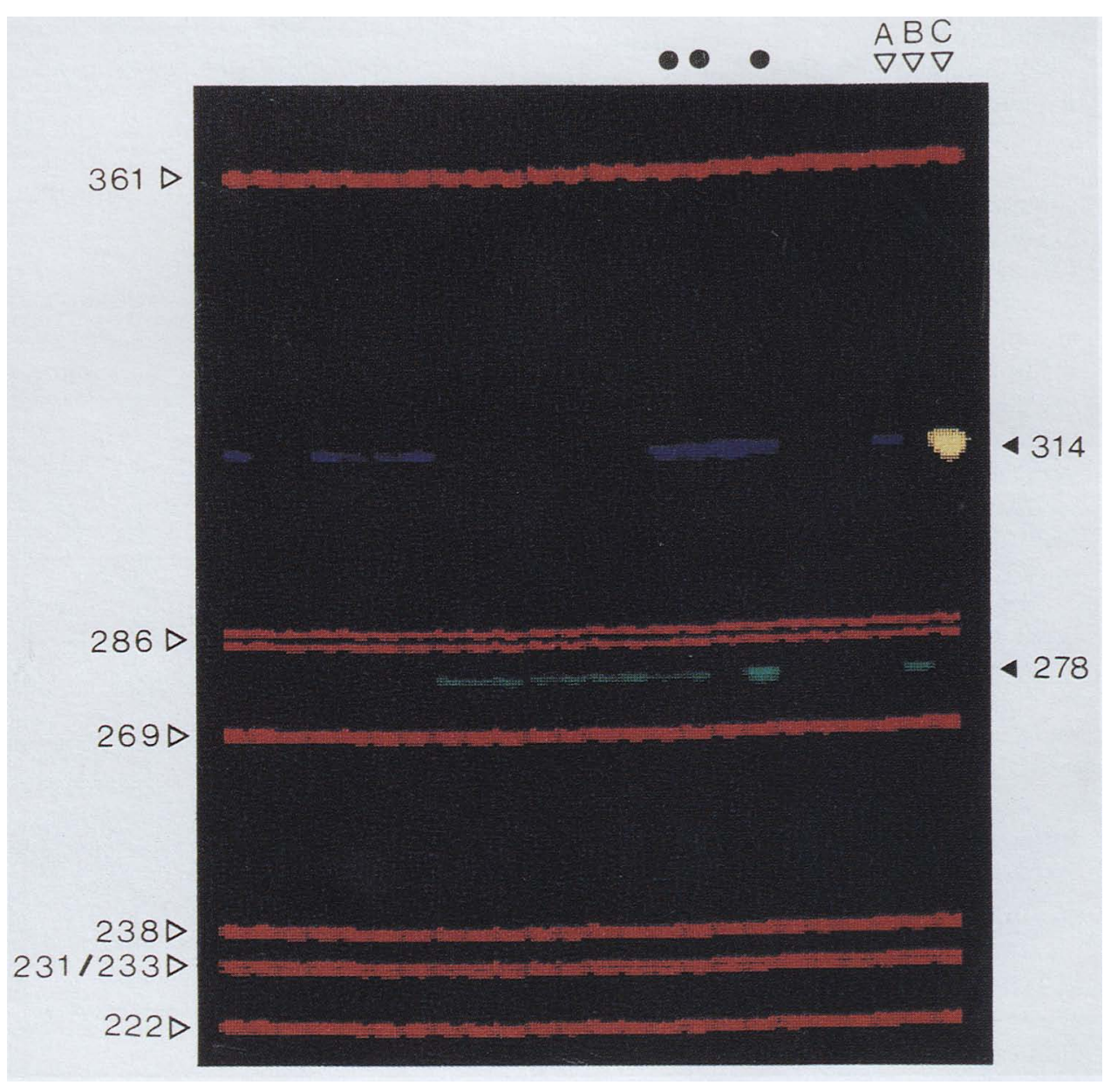

FIGURE 3 Six percent polyacrylamide-urea gel of fluorescently labeled PCR products. The GENESCAN-2500P internal standards appear as red bands (size in bp at left) in all tracks. The positive controls for serotype A (blue, $314 \mathrm{bp}$ ), serotype B (green, $278 \mathrm{bp}$ ), and serotype C (yellow, $314 \mathrm{bp}$ ) were loaded in the three tracks at the right (labeled A, B, and C). The remaining tracks were loaded with PCR products derived from clinical samples and demonstrate either no detectable infection with C. trachomatis, infection with serotype A, infection with serotype B, or mixed infection with serotypes $A$ and $B$ (the latter marked by $)$ ). 


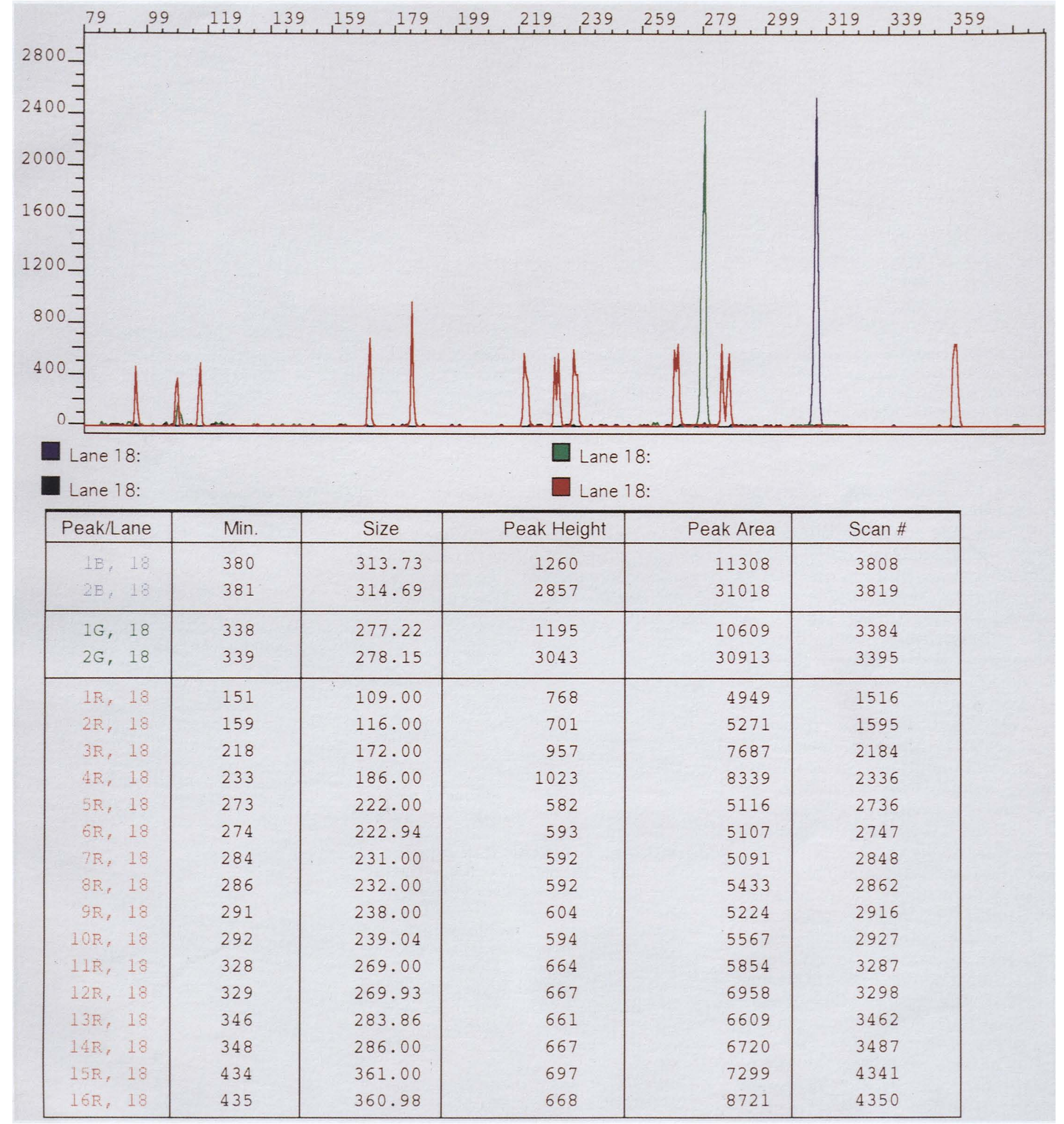

FIGURE 4 Example electrophoretogram derived from $C$. trachomatis serotype A and B mixed infection. The electrophoretogram, produced by the GENESCAN 672 software, represents a single track of the gel image (Fig. 3). The horizontal axis denotes fragment size, and the vertical axis denotes band intensity. Internal standards are shown in red, serotype A-specific bands in blue, and serotype B-specific bands in green. The accompanying table gives information on calculated fragment sizes and areas. The presence of both a green $(278 \mathrm{bp})$ peak and a blue ( $314 \mathrm{bp}$ ) peak indicates the mixed infection. 


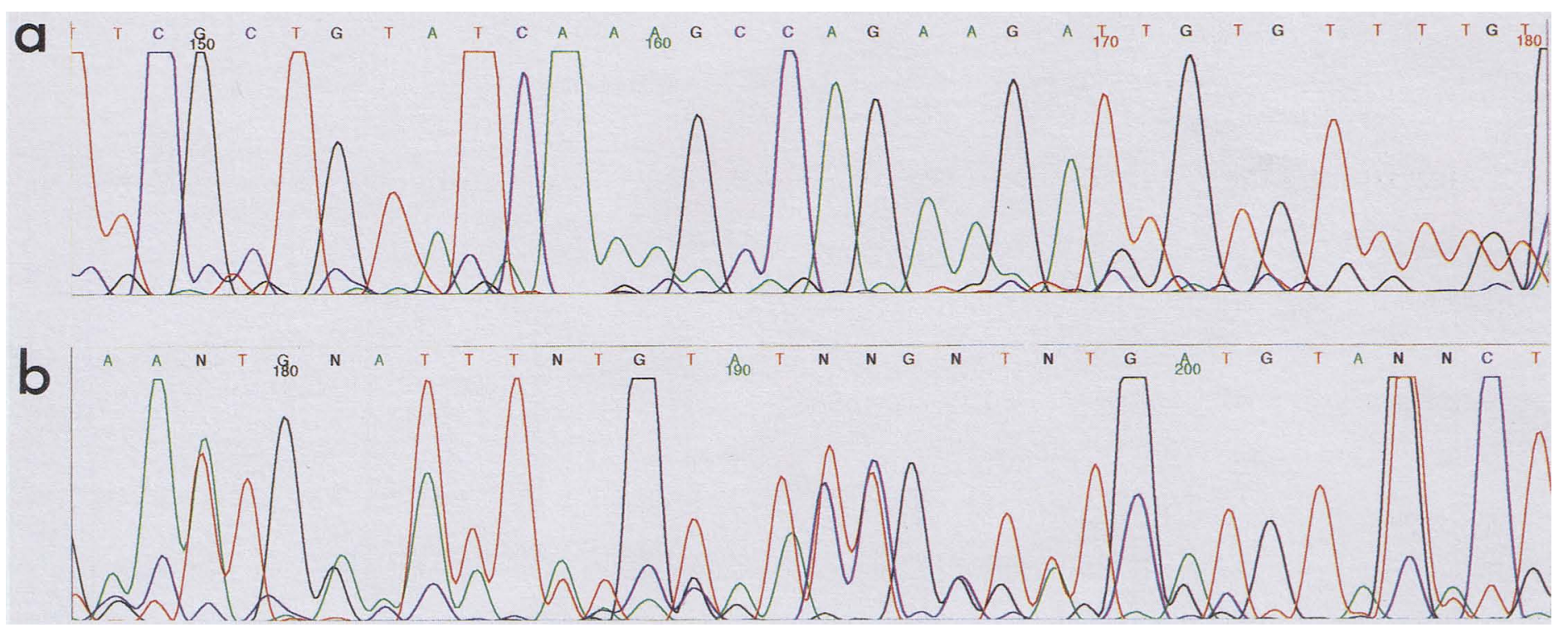

FIGURE 5 DNA sequences and chromatograms of variable segment I derived from PCR-amplified MOMP gene from two conjunctival swabs. The graphic representation was generated by ABI 373 Analysis Software (v. 1.2.0), with each base represented by a different color. (a) An example of $C$. trachomatis serotype A infection; $(b)$ mixed serotype infection. The latter is demonstrated by the inability to accurately base-call at certain positions (N) owing to chromatogram ambigiuties.

( $\mathrm{N}$ in Fig. 5b), the DNA analysis software detects two bases.

To assess the potential value of this nested genotype PCR for clinical and epidemiological studies it was necessary to establish the sensitivity of the test. We analyzed all 1363 clinical samples by PCR for C. trachomatis plasmid genes. ${ }^{(9)}$ Ostergaard et al. ${ }^{(9)}$ established that this plasmid PCR detected $10^{-17} \mathrm{~g}$ of chlamydial DNA and showed $100 \%$ sensitivity and $99 \%$ specificity when compared with cell culture plus a commercial EIA kit (IDEA). In all of our ocular samples where plasmid DNA was detected by PCR, the nested genotyping PCR gave a positive result indicating comparable levels of sensitivity.

We developed this drop-in/drop-out nested PCR for studies on trachoma in The Gambia. Advantages include the use of a transport medium that permits other tests, for example, antigen detection, a simple nontoxic DNA extraction procedure, and the feasibility of handling large numbers of clinical samples. The ability to accommodate $>40$ samples on a single GENESCAN run and to achieve two runs in a 24 -hr period means that analysis of PCR products is not the rate-limiting step.

\section{ACKNOWLEDGMENTS}

We thank Dr. D. Mabey and Dr. R. Bai- ley, London School of Hygiene and Tropical Medicine, UK, for providing conjunctival swabs from the trachoma endemic village of Jali, The Gambia. This work was supported by a grant from the Edna McConnell Clarke Foundation, New York.

\section{REFERENCES}

1. Frost, E.H., S. Deslandes, S. Veilleux, and D. Bourgaux-Romoisy. 1991. Typing Chlamydia trachomatis by detection of restriction fragment length polymorphism in the gene encoding the major outer membrane protein. J. Infect. Dis. 163: 1103-1107.

2. Rodriguez, P., A. Vekris, B. de Barbeyrac, B. Dutilh, J. Bonnet, and C. Bebear. 1991. Typing of Chlamydia trachomatis by restriction endonuclease analysis of the amplified major outer membrane protein gene. I. Clin. Microbiol. 29: 1132-1136.

3. Sayada, C., E. Denamur, J. Orfila, F. CataIan, and J. Elion. 1991. Rapid genotyping of the Chlamydia trachomatis major outer membrane protein by the polymerase chain reaction. FEMS Microbiol. Lett. 83: 73-78.

4. Hayes, L., R. Bailey, D. Mabey, I. Clarke, M. Pickett, P. Watt, and M. Ward. 1992. Genotyping of Chlamydia trachomatis from a trachoma-endemic village in the Gambia by a nested polymerase chain reaction: Identification of strain variants. $J$. Infect. Dis. 166: 1173-1177.

5. Erlich, H.A., D. Gelfand, and J.J. Sninsky.
1991. Recent advances in the polymerase chain reaction. Science 252: 1643-1651.

6. Campbell, L.A., M. Melgosa, D.J. Hamilton, C.-C. Kuo, and J.T. Grayston. 1992. Detection of Chlamydia pneumoniae by polymerase chain reaction. J. Clin. Microbiol. 30: 434-439.

7. Salari, H. and M. Ward. 1981. Polypeptide composition of Chlamydia trachomatis. I. Gen. Microbiol. 123: 197-207.

8. Sambrook, J., E.F. Fritsch, and T. Maniatis. 1989. Molecular cloning: A laboratory manual, 2nd ed., pp. 11-46. Cold Spring Harbor Laboratory Press, Cold Spring Harbor, New York.

9 Ostergaard, L., S. Birkelund, and G. Christiansen. 1990. Use of polymerase chain reaction for detection for Chlamydia trachomatis. J. Clin. Microbiol. 28: 12541260.

Received July 6, 1993; accepted in revised form October 19, 1993. 


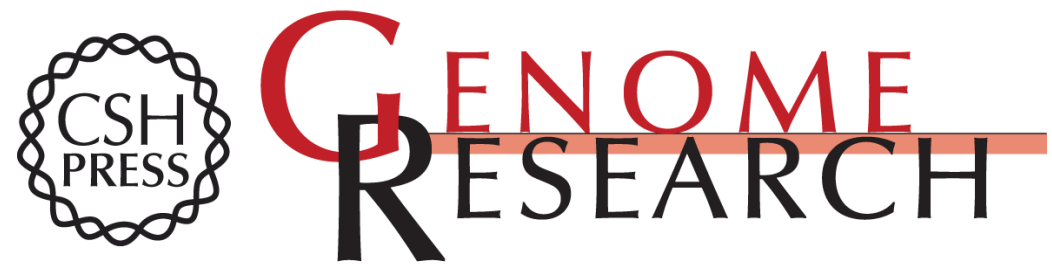

\section{Genotyping ocular strains of Chlamydia trachomatis by single-tube nested PCR.}

S Pecharatana, M A Pickett, P J Watt, et al.

Genome Res. 1993 3: 200-204

References This article cites 8 articles, 4 of which can be accessed free at: http://genome.cshlp.org/content/3/3/200.full.html\#ref-list-1

License

Email Alerting

Receive free email alerts when new articles cite this article - sign up in the box at the Service top right corner of the article or click here.

\section{Affordable, Accurate Sequencing.}

\section{gencove}

To subscribe to Genome Research go to: https://genome.cshlp.org/subscriptions 